DOI: https://doi.org/10.47405/aswj.v6i3.169

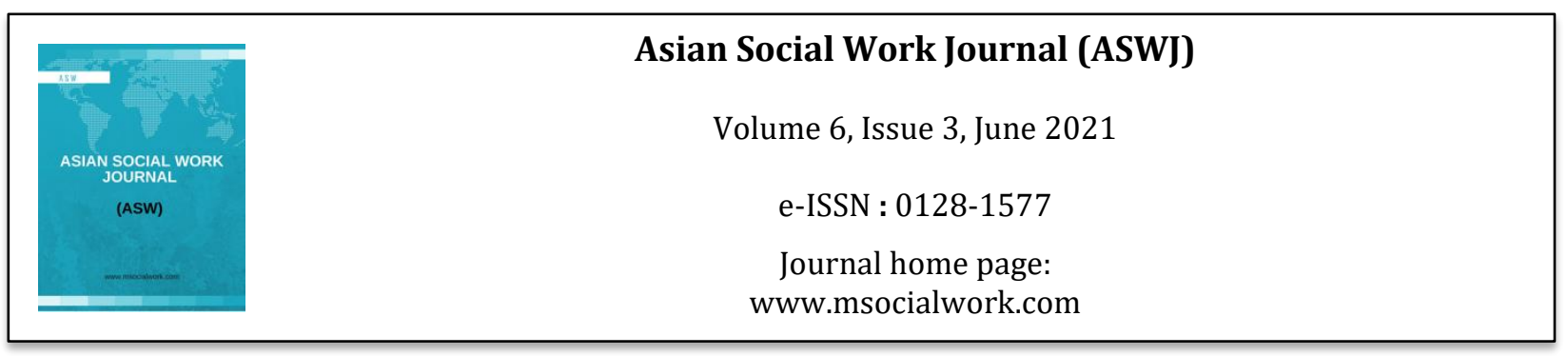

\title{
Self-Empowerment of Recipients of Assistance from the Malaysian Social Welfare Department through Productive Welfare
}

\author{
Zakiyah Jamaluddin', Norzalinda Mohd Ali Hanafiah' ${ }^{1}$ \\ ${ }^{1}$ School of Applied Psychology, Social Work \& Policy, Universiti Utara Malaysia (UUM), Malaysia \\ Correspondence: Zakiyah Jamaluddin (zakiyah@uum.edu.my)
}

\begin{abstract}
The Productive Welfare Approach and the "2-Year Exit Policy" (2YEP) are introduced by the Department of Social Welfare Malaysia (JKM) to help recipients of welfare assistance (clients) towards living independently and provide the ability to survive without relying on indefinite assistance. This study aims to identify the empowerment of recipients after being involved in entrepreneurship programs through the Launching Grant provided by JKM. This study employs the survey method using questionnaires. A total of 234 respondents were involved in the study: 107 respondents from the Northern Zone, and a total of 127 respondents from the Eastern Zone from 17 Social Welfare District Offices (PKMD) in both zones. The data collection was done between September 2016 to February 2017. The results show that the majority of respondents are self-employed/sole proprietors (85\%) with many involved in the food and beverage-type business (58.1\%). In terms of selfenrichment/empowerment, respondents' levels are at moderate to high levels. They are responsible for the work, for what they do, and for the results of their actions. The Productive Welfare Approach and the 2YEP program have to some extent, helped in increasing revenue and reducing clients' dependency on JKM's assistance. However, better implementation of the program and continuous monitoring can help clients increase their motivation and thus, contribute to eradicating poverty among receivers of assistance.
\end{abstract}

Keywords: "2-Year Exit Policy" (2YEP), productive welfare, recipients, empowerment, Social Welfare Department

\section{Introduction}

Generally, the poverty rate in Malaysia has been successfully reduced significantly from $52.4 \%$ in 1970 to $3.8 \%$ in 2009. In the Tenth Malaysia Plan (10thMP) 2010-2015, the poverty rate was projected to decrease to $2 \%$ and the average income for the lowest $40 \%$ of households increased from RM1,440 in 2009 to RM2,300 in 2015 (Tenth Malaysia Plan, 2010). Meanwhile, in 2014, the poverty rate decreased to $0.6 \%$ and further to $0.4 \%$ in 2016 (Department of Statistics Malaysia, 2017). Although the incidence of poverty is low, the rate does not reflect the true situation of poverty at the grass-root (Samat, Elhadary $\&$ Rainis, 2016). The poor and the hard-core poor still depend on the assistance provided by the government through the Social Welfare Department (JKM). 
DOI: https://doi.org/10.47405/aswj.v6i3.169

It is difficult to get the exact number of JKM recipients, as each state keeps its own record. However, usually, data on the poor can be referenced through the eKasih system which is a database of poor families created at the national level to help plan, implement, and monitor poverty programs. The poverty status criteria are based on household per capita income that falls below the Poverty Line Income (PGK) 2007 which is RM830 in Peninsular Malaysia, RM1,090 in Sabah, and RM920 in Sarawak (Ministry of Women, Family and Community Development, 2015). Also, those who are eligible to register and be included in eKasih are households with an income of less than RM1,000 per month in rural areas and RM1,500 in urban areas (Kedah Social Welfare Department, 2015). However, according to the Department of Statistics Malaysia, the PGK has been revised and set to RM2,208 in 2020, based on calculations made according to the methodology in 2019 (Harian Metro, 2020).

Financial assistance provided by JKM aims at sustaining income to meet the needs of daily life, improve living standards and as a stimulant allowance to target groups (such as People with Disabilities, Single Mothers, and JKM's clients) to be interested in working and eventually be independent. The main objective is to help individuals or families who are less able and in dire need to alleviate their financial difficulties temporarily until they can be independent (Department of Social Welfare, 2020).

Welfare assistance is commonly seen as a long-term program that maintains dependency and in general, recipients of assistance are seen as dependent and problematic. Therefore, JKM is committed to the effort to undertake the productive welfare approach or "Productive Welfare" which has been initiated under the 10thMP starting in 2010. The productive welfare approach is a comprehensive human development approach with an emphasis on individual awareness, changed attitudes, good work ethic, acquiring new skills or upgrading existing skills, and capacity building. Productive welfare is an approach to help recipients of welfare assistance towards independent living and to be able to continue their survival; so as not to rely on assistance for survival/empowering the client (recipient of assistance) to continue improving one's life; as well as intensifying programs towards human capital development. Through this approach, aid recipients can be transformed from a cocoon of negative attitudes to capable, confident, and independent individuals. The objective of this study is to look into the effort of the JKM by initiating the Productive Welfare approach to help the financial assistance recipients to increase their income through entrepreneurial activity and to exit the poverty line (Zakiyah \& Norzalinda, 2018; Zakiyah \& Norzalinda, 2020; Department of Social Welfare, 2020).

\section{Literature Review}

The productive welfare approach is not new especially abroad, predominantly in western countries that have long practiced productive welfare as one of the ways to deal with budget constraints in their welfare system. Hudson and Kuhner (2009) conducted a study on 23 countries Organization for Economic Cooperation and Development (OECD) which practiced productive welfare and protective elements in their social policies for three different periods, namely in the years 1994, 1998 and 2003.

Most analyse suggest that the process of globalization and the K-economy (knowledge-based economy) has encouraged many developed countries to shift towards productive welfare focusing on social investment. However, welfare typology focuses more on social protection rather than on social investment. Hudson and Kuhner (2009) also found that most welfare countries are changing from a protectionist approach to welfare, and at the same time, some countries combine both approaches in their social policies.

For example, South Korea has also adopted this approach since 2000. The concept of productive welfare is also influenced by the "British Third Way" approach introduced by Anthony Giddens (Han, 2002). The crisis of economic downturn in 1997 caused South Korea to stop providing direct financial assistance to the citizens. Instead, South Korea changed its approach from charity to employment. Apart from protecting the less fortunate and marginalised in the welfare system, the approach provides employment opportunities to recipients. Indirectly this approach has been transformed from mere welfare assistance to a market system with welfare. As a result, the National Basic Livelihood Security System (NBLSS) Act was introduced in 2000 which further expanded the target group of recipients, 
DOI: https://doi.org/10.47405/aswj.v6i3.169

namely those who can work were also eligible to receive income support from the government (Cheon, 2003; Jisun, 2008; Joon, 2014).

The approach of the social assistance program in NBLSS provides financial, medical, housing, educational, childbirth, funeral arrangements, and "self-reliance" benefits. The NBLSS system provides ancillary benefits to ensure that recipients reach the minimum wage guaranteed by the government. A poverty line has been set by the government as the minimum level of living standards. Once household income increases beyond the poverty line, the benefits given will be terminated (Jisun, 2008; Joon, 2014). This program known as the "self-reliance" (independent) program has become one of the main principles of why productive welfare was introduced. As a result of the implementation of this program, there were 1.5 million recipients (852,000 households) in 2007 which was $3.2 \%$ of the total population of South Korea (Cheon, 2003). Meanwhile, in 2014, the NBLSS Act has benefited 1.3 million recipients or $2.7 \%$ of the total population.

Compared to western and East Asia countries, productive welfare is a new approach used in Malaysia starting in 2010. According to the Department of Social Welfare (2011), productive welfare is a method of approach that was first introduced in 2009 and implemented in 2010. Productive welfare is developed to assist in empowering clients through human capital development. Productive welfare is believed to assist clients towards independent living and survival so that clients do not rely too much on continuous welfare assistance and can continue living on their own. The Productive Welfare Division was established in January 2014 following the reorganisation of JKM which was previously known as the Socio-Economic Development and Assistance Division. Starting in 2017, the Division has four main sections, namely the Assistance Management, the Productive Client Development, the Crisis and Disaster, and the Social Entrepreneurship (Department of Social Welfare, 2016).

This approach also takes into account the aspect of increasing the client's motivation to be ready to work after obtaining skills training that suits his/her abilities. The client's involvement in employment is continuous to ensure the clients do not return to welfare assistance for living expenses. This approach is implemented to reduce the total community dependency syndrome on government assistance as well as to achieve the goal of JKM towards making aid services for a period not exceeding two years (Department of Social Welfare, 2011).

Welfare entrepreneurs who meet the goal of this approach can be considered to have been successful. A productive welfare approach takes into account aspects of the client's motivation, appropriate skills training based on the client's abilities, the client's continuous involvement in employment and the client's ability not to return to welfare assistance for living needs. Malaysia has implemented the productive welfare approach based on assessments from 2005-2008 but the success level is still low (Hudson \& Kuhner, 2012).

Through this productive welfare approach, several assistance programs are implemented including the Launching Grant Assistance (GP). GP assistance is in the form of a one-off initial capital injection to start a business of RM2700 which is channelled to those who are categorized as needing help but still able to work (productive). The purpose of this assistance is to help the clients develop themselves by venturing into business as well as helping to further increase the client's productivity to live independently. Besides, through GP assistance, clients will benefit from strategic cooperation between JKM and inter-agency in managing funding, skills training, expertise in entrepreneurship as well as consistent monitoring to help clients become independent (Department of Social Welfare, 2011).

One of the strategies of the social welfare approach is to empower or enrich individuals who do business. Currently, entrepreneurship is considered a fundamental driver toward achieving and maintaining a competitive nature (Zahra, 1999). In this context, empowerment can also be interpreted as a tool for leadership. Empowerment is also said to be a perception to enable (Corsun \& Enz, 1999) the empowerment of the mind (Spreitzer, 1995; 1996) and the results of the leaders' actions and conducts.

Studies on productive welfare are very limited so far. However, there are studies conducted on financial assistance provided by the Department of Social Welfare Malaysia (JKMM) to recipients of assistance. 
DOI: https://doi.org/10.47405/aswj.v6i3.169

Mohamad Zahir (2009) conducted a study on the perceptions of aid recipients towards JKMM in the Federal Territory as well as the changes they undergo in terms of economic, social, and self-identity. A total of 157 respondents consisting of recipients were selected by simple sampling and data collected using a questionnaire. The results of the study showed that the majority of recipients earned less than RM500 per month and the majority received assistance under the General Assistance scheme (56.7\%).

The study also found that there was a significant relationship between the perceptions of recipients on JKMM's customer service with demographic factors, educational status, and family income. The results also showed that the recipient's perception of the assistance scheme was at a high level where the overall mean value of the variables studied was 3.71. Several suggestions have been submitted to the management to improve the implementation of the assistance scheme provided. Researchers have also suggested that future studies should also look at efforts to strengthen the ability of aid recipients to be independent and not rely on assistance from relevant parties.

Radieah and Hamoon (2018) studied 53 1AZAM participants in Penang and found that respondents' income increased after participating in the program. However, several weaknesses have been identified, namely, the performance of key indicators (KPIs) was set at RM300 (KPI) compared to RM980 (PGK), wastage of funds (provision of equipment that did not cater to the participants' needs), and weaknesses in the eKasih system (did not reflect the actual poverty situation of eKasih participants). Zurinawaty, Nur Saadah, and Nor Jana (2020) examined the level and relationship of well-being, behaviour, and financial experience among AZAM Tani FAMA participants involved in receiving productive welfare assistance. A total of 300 respondents were selected as the study sample. They found that the level of the financial well-being of respondents (97.3\%) was at a moderate level. Also, there was an increase in income after participating in the AZAM Tani program, where $35.7 \%$ has earned incomes between RM2001-RM3000 per month, compared to $8.7 \%$ before participating. The researchers also concluded that there were still weaknesses in terms of financial behaviour and knowledge among respondents that needed to be guided by social workers, especially in JKM.

Several studies examining the pilot project of the 2YEP program found that the program was beneficial not only to the recipients of JKM's assistance but also to JKM, and should be continued (Sharifah, et al., 2017; Noraida, et.al., 2018, Khairul, 2019; Putri et.al., 2020). The 2YEP Phase 1 (2016-2018) program has successfully saved government spending of RM1.9 million a year with a total of 575 JKM's clients having their monthly assistance terminated (Noraida, et.al., 2018) and eventually, increased to 674 people in 2019 (Khairul, 2019).

There have been many studies on empowerment but there have been no studies linking empowerment with productive welfare. According to Lightfoot (1986), empowerment is defined as someone who has opportunities in autonomy, making choices, shouldering responsibilities, and involvement in the organization. Empowerment is an active engagement process in which individuals and groups gain more power in their lives, establish rights, and reduce marginalisation (Maton, 2008). Several studies focus on empowerment. Among them is London (1993) who examined the relationship between empowerment, employer support for career development, and the components of career motivation (career resilience, career identity, and career vision). The researcher conducted two phases of the study that included employers and employees. In the first phase study, it was found that there was a positive relationship between career identity and career vision with employer rating (employees were empowered and received support in career development). This first phase study involved a total of 183 employees. In the second phase study, a total of 59 employees were selected as respondents. The results showed that career identity was divided into two, namely work identity and organizational identity. It was also found that employees with a higher organizational identity were those given a lower rating on empowerment by their employers.

Chakir and Guneri (2011) conducted a study on the factors that contributed to the empowerment of 248 Turkish women who migrated to London, Britain. Their study focused on the role of demographic factors (length of stay, education, and language levels), perceived discrimination, social support, acculturation attitudes (separation, assimilation, integration, and marginalisation), and psychological challenges in predicting empowerment among respondents. The results of the study indicated that 
DOI: https://doi.org/10.47405/aswj.v6i3.169

acculturation attitudes (separation, assimilation, and marginalization) and psychological challenges were negative predictors of empowerment. Meanwhile, acculturation (integration) and social support were positive predictors of empowerment. Regression test results showed that psychological challenges were the most significant empowerment predictors, in addition to the level of education and social support. More specifically, the psychological challenges that were at a low level, together with higher levels of education, and social supports, were predictors for stronger empowerment.

Successful entrepreneurs need to identify the potential within them. This is supported by individual and environmental factors so that the entrepreneurs know their self-abilities which can be developed through entrepreneurship, as well as supported by appropriate training so that they can develop themselves and compete with other entrepreneurs. Typically, welfare entrepreneurs are referred to other agencies for training (Rohayu, Marina, Ahmad, Sarebah, Maziana, Anizam, \& Azmanirah, 2010). Sabrina (2019) explained that individual or self-empowerment developed individuals to become independent by the ability to think, decide and solving problems.

According to Rohayu, et al., (2010), the application of appropriate andragogy education in training modules can produce successful entrepreneurs whether they were educated or otherwise. On the contrary, Chee, Filzah, Cheng, Norashidah, Jasmani \& Haim (2012) propose that knowledge played an important role. This was because of the lack of knowledge about the field of business ventured by entrepreneurs influenced them in the ability to propel the business to greater heights.

Meanwhile, Sarimah, Aidah, and Norlizah (2020) conducted a study on how to strengthen the role of community colleges in empowering women entrepreneurs. They proposed four improvements, namely the need to have complete data on women entrepreneurs in Malaysia as a source to analyse the profile of entrepreneurs; elevating community colleges as a Lifelong Learning hub that serves as a centre for skills education and knowledge development; establishing strategic and consolidated action plans for women entrepreneurs; and providing business simulation projects.

This article focuses on the empowerment of recipients after being involved in entrepreneurship programs through the GP given by JKM. The focus of the study is on the recipients of JKM's GP assistance (clients).

\section{Methodology}

Based on JKM's (2012) statistics, there are 527 GP recipients throughout Malaysia. The population in this study is the recipients of GP assistance in the JKM Northern Zone (Perlis, Kedah, and Penang) and the Eastern Zone (Terengganu, Kelantan, and Pahang). In this study, purposive sampling was used, where only those who received GP assistance and were willing to be interviewed are selected as respondents.A total of 234 respondents were involved in this study. This study was done between 2016 t0 2018. The process of data collection took between 6 months ie. September 2016 to February 2017. The researchers need to obtain permission from the JKM to facilitate the study before the data collection can be done. Permission letter is requested to JKMM headquarters in Kuala Lumpur and application is also made through MYResearch JKM online. Once permission has been obtained, the researchers contacted each JKM and the District Social Welfare Office (PKMD) involved in this study. JKM/PKMD will contacted clients to attend the relevant PKMD office to facilitate the collection of data. The data collection process was done with the clients present at the JKM/PKMD office. There are also questionnaires posted to PKMD involved in regards to time constraints and distance by the researchers. For this method, the staff will ensure that the questionnaire will be answered by the respondent and returned to the researchers.

The current study is a quantitative research employing the survey method through questionnaires. The survey contains questions on demographics and enterprises and businesses, as well as selfempowerment. The information section on enterprises and businesses was constructed and modified from the questionnaires by Thuaibah @ Suaibah et al. (2004). On the other hand, the self-empowerment 


\section{Asian Social Work Journal (ASWJ), Volume 6, Issue 3, (page 1 - 12), 2021 \\ DOI: https://doi.org/10.47405/aswj.v6i3.169}

section was constructed and modified from the questionnaire "The Perception of Empowerment Instrument (PEI)" by Roller (1998) and has gone through the process of back to back translation. There are 15 items in "The Perception of Empowerment Instrument (PEI)" with a-5 point Likert scale starting with 1 - "strongly disagree" to 5 - "strongly agree". This instrument measures the three dimensions of empowerment namely autonomy, involvement, and responsibility. The autonomy sub-scale contains 5 items, the involvement sub-scale consists of 6 items and the responsibility sub-scale contains 4 items. The higher the score obtained will indicate a higher level of self-empowerment among the respondent.

Data was analysed using the SPSS method (Statistical Package for Social Science) version 24. The information and data obtained are analysed using the descriptive statistical analysis method involving analysis using percentage and mean. A pilot study was conducted on 30 respondents from JKMN Perlis before the field study was undertaken. The Cronbach Alpha's value for the pilot study conducted was .805. Only descriptive analysis was reported in this study.

\section{Result}

\section{Demographic Profile of Respondents}

This study involved 17 District Social Welfare Offices (PKMD) in the Northern and Eastern Zones, Peninsular Malaysia. Table 2 shows the list of PKMD from the zones involved. The Northern Zone consists of JKMN Perlis, four PKMDs in Kedah, and two PKMDs in Penang. Meanwhile, the Eastern Zone consists of four PMKDs in Kelantan, three PKMDs in Terengganu, and three PKMDs in Pahang. A total of 234 respondents were involved in the study, namely 107 respondents from the Northern Zone, and a total of 127 respondents from the Eastern Zone.

Table 1: Number of Respondents from the Northern and Eastern PKMDs Zones

\begin{tabular}{|c|c|c|}
\hline State & Frequency & Percentage \\
\hline Perlis (JKMN) & 40 & 17.0 \\
\hline Total & 40 & 17.0 \\
\hline \multicolumn{3}{|l|}{ Kedah } \\
\hline PKMD Alor Setar & 8 & 3.4 \\
\hline PKMD Kubang Pasu & 9 & 3.8 \\
\hline PKMD Pendang & 11 & 4.7 \\
\hline PKMD Kuala Muda & 15 & 6.4 \\
\hline Total & 43 & 18.3 \\
\hline \multicolumn{3}{|l|}{ Penang } \\
\hline PKMD Seberang Perai Tengah & 8 & 3.4 \\
\hline PKMD Seberang Prai Utara & 16 & 6.8 \\
\hline Total & 24 & 10.2 \\
\hline \multicolumn{3}{|l|}{ Kelantan } \\
\hline PKMD Kota Bharu & 10 & 4.3 \\
\hline PKMD Bachok & 13 & 5.5 \\
\hline PKMD Pasir Mas & 10 & 4.3 \\
\hline PKMD Tanah Merah & 10 & 4.3 \\
\hline Total & 43 & 18.4 \\
\hline \multicolumn{3}{|l|}{ Terengganu } \\
\hline PKMD Kuala Terengganu & 8 & 3.4 \\
\hline PKMD Hulu Terengganu & 18 & 7.7 \\
\hline
\end{tabular}


DOI: https://doi.org/10.47405/aswj.v6i3.169

PKMD Kemaman

Total

Pahang

PKMD Jerantut

PKMD Temerloh

PKMD Lipis

Grand Total
19

45

8.1

19.2

Table 2 shows the respondents' backgrounds including gender, age, race, religion, marital status, and level of education. In terms of gender, a total of 72 respondents $(30.8 \%)$ are male and $162(69.2 \%)$ are female respondents. In terms of age, the majority (38.9\%) are between $41-50$ years old, $31.2 \%$ are between $31-40$ years, while the fewest $(0.4 \%)$ are 20 years old and below.

In this study, a total of $226(96.6 \%)$ respondents are Malays and Muslims, two respondents $(0.9 \%)$ are Chinese and Buddhist, and six respondents $(2.6 \%)$ are Indian and Hindu. The majority of respondents $(44.0 \%)$ are married, while $37.6 \%$ are single mothers. In terms of the level of education, a total of six respondents $(2.6 \%)$ never went to school, 37 respondents $(15.8 \%)$ had primary school education, 163 respondents $(69.7 \%)$ graduated from high school, 15 respondents $(6.4 \%)$ had colleges/diplomas, while four respondents $(1.7 \%)$ have university degrees, and the remaining $9(3.8 \%)$ have other levels of education.

Table 2: Demographics of Respondents

\begin{tabular}{lrr}
\hline Respondents' Demographic & Frequency & Percent \\
\hline Gender & 72 & \\
Male & 162 & 30.8 \\
Female & $\mathbf{2 3 4}$ & 69.2 \\
Total & & $\mathbf{1 0 0 . 0}$ \\
Age & 1 & \\
20 years and below & 32 & 0.4 \\
21-30 years old & 73 & 13.7 \\
31-40 years old & 91 & 31.2 \\
41-50 years old & 37 & 38.9 \\
51 years and above & $\mathbf{2 3 4}$ & 15.8 \\
Total & & $\mathbf{1 0 0 . 0}$ \\
& & \\
Race and Religion & 226 & 96.6 \\
Malay (Muslim) & 2 & 0.9 \\
Chinese (Buddhist) & 6 & 2.6 \\
Indian (Hindu) & $\mathbf{2 3 4}$ & \\
Total & & $\mathbf{1 0 0 . 0 0}$ \\
Marital Status & & \\
Single & 39 & 16.7 \\
Married & 103 & 44.0 \\
Widower & 4 & 37.6 \\
Widow & 88 & $\mathbf{1 0 0 . 0}$ \\
Jumlah & $\mathbf{2 3 4}$ &
\end{tabular}

\section{Education Level}

No schooling 
DOI: https://doi.org/10.47405/aswj.v6i3.169

Primary school

\section{Enterprise and Business Information}

This section displays information related to the respondent's enterprise and business. It relates to a business method, type of business, duration of business, age of starting a business, experience, duration of business experience, assistant or employee, number of employees, and net income. The results of the study found that most GP recipients at $85 \%$ are sole proprietors. While the rest is co-own with friends $(5 \%)$, trading online (2\%) and also running other businesses $(8 \%)$.

The types of enterprises and businesses conducted by the respondents are shown in Table 3. It is found that the majority of respondents (58.1\%) run food and beverage-based businesses. Meanwhile, $12.8 \%$ are involved in the cloth and clothing-based business, namely sewing shops, $6 \%$ running a retail/grocery store, and 5.6\% running agricultural products, vegetables, and fruits. There are also $13.7 \%$ of respondents who run other enterprises and businesses such as livestock, motorcycle workshops, shoe stores, and frozen foods.

Table 3: Types of Enterprises and Businesses

\begin{tabular}{lrr}
\hline Types of Enterprises and Businesses & Frequency & Percent \\
\hline Food and beverage & 136 & 58.1 \\
Fabric and clothing & 30 & 12.8 \\
Grocery & 14 & 6.0 \\
Agriculture products, vegetables and fruits & 13 & 5.6 \\
Traditional medicines & 2 & 0.9 \\
Beauty products & 7 & 2.9 \\
Others & 32 & 13.7 \\
Total & $\mathbf{2 3 4}$ & $\mathbf{1 0 0}$ \\
\hline
\end{tabular}

In terms of the total net income received by the respondents in a month, the results show that a total of $98(42 \%)$ respondents earned a net income of RM 500 and below. It is followed by 19 respondents (8\%) earning as much as RM 1001-RM 1500 per month, with a total of 8 respondents (3\%) were found to earn an income of RM 1501-RM 2000, and the remaining 11 respondents (5\%) earned a net income of RM 2001 and above. Table 6 shows the net income rate earned by the respondents in a month.

\section{Self-empowerment}

Table 4 shows the mean values of the respondents' self-empowerment factors. The results of the study found that the highest mean value was "responsible for the work" (4.38), followed by "responsible for what was done" (4.33) and "responsible for the results of their actions" (4.31). The low mean was obtained by the item "involved in the change" (3.84). Overall, the self-empowerment factors of the respondents were at a moderate to a high level.

Table 4: Self-empowerment

\begin{tabular}{|c|c|c|}
\hline No & Item & Mean \\
\hline 1 & Free to decide what to do & 4.05 \\
\hline 2 & Involved in change & 3.84 \\
\hline
\end{tabular}


DOI: https://doi.org/10.47405/aswj.v6i3.169

\begin{tabular}{cll}
\hline 3 & Involved in the decision-making process & 4.02 \\
4 & Creative in problem-solving & 4.03 \\
5 & Responsible for what is done & 4.33 \\
6 & Responsible for what has been set & 4.30 \\
7 & Responsible for the outcome of the actions & 4.31 \\
8 & Responsible for work & 4.38 \\
9 & Fully involved in future planning & 4.26 \\
10 & Valuable ideas & 4.22 \\
\end{tabular}

\section{Discussion}

The results show that the level of self-empowerment of GP recipients is at a moderate to a high level because the empowerment factor is the determinant of the success of a business ventured by entrepreneurs. The analysis shows that the attitude of successful entrepreneurs is that they must be responsible for the work done, involved in the decision-making process in business, responsible for what has been set, and also always creative in finding solutions to problems faced to ensure the business can be in the market for the long run. The findings of the present study support Spreitzer's (1995) view that competency and confidence of entrepreneurs in performing their tasks well, the seriousness in performing work, and feeling that every work performed was meaningful and important in life, can have an impact and influence in how they conducted their businesses.

As stated by Lightfoot (1986) empowerment enables a person to make decisions, take responsibility, be motivated, creative, work hard and show a high level of confidence in decision making. Undoubtedly, the respondents in this study have shown that they are responsible for everything they do in their business from work implementation to the decision-making stages. This study is also in line with Sabrina (2019) which found that self-empowerment can improve their business.

Nevertheless, some aspects should be given due attention. Although the respondents of the study show a positive development in terms of increasing income and the attitude of wanting to be independent, JKM should also take the role of not only providing financial assistance for the Launching Grant (GP). Instead, what is more important is regular and continuous monitoring as suggested by previous researchers (Sharifah, et al., 2017; Noraida, et.al., 2018, Khairul, 2019; Putri et.al., 2020).

\section{Conclusion}

The approach taken by the JKM in productive welfare and "2YEP" can indirectly help GP recipients to break free from poverty and further improve their standard of living and social functioning. Selfempowerment to some extent has a huge impact on the sustainability of themselves and their businesses. Furthermore, the role of JKM should be enhanced. Effective management and monitoring can help change the lives of aid recipients for the better and to be more independent, in line with the goals of productive welfare and 2YEP.

Productive welfare is a new approach in Malaysia, compared to the western and eastern countries. The objective of productive welfare is to change the mentality of the financial recipients' of JKM to become more independent and not only depends on government's financial assistance. This approach can be an effective way to enable clients to live independently, and improve the standard of living of the poor. The absence of case worker to monitor and oversee the smooth running of the new operation could be a problem to the productive welfare approach. Currently the available case workers are not able to run the program as their current workloads servicing their target group is huge. However, efforts made by the JKM are very good and significant in helping to realize the government's intention to reduce poverty and the dependency of the poor on government assistance. Productive welfare approach can significantly 
DOI: https://doi.org/10.47405/aswj.v6i3.169

give a huge impact in eradicating poverty in Malaysia and lessen the burden of the government, especially the JKM to gives financial assistance to the client's. In addition, there has been very few studies on productive welfare in Malaysia. Therefore, this study can contribute significantly to productive welfare in Malaysia.

\section{Acknowledgement}

This research was supported by the Ministry of Higher Education (MOHE) through Fundamental Research Grant Scheme (FRGS), Code S/O 13254, and the authors wish to thank to the RIMC, Universiti Utara Malaysia for the management and administration of this research.

\section{References}

Chakir, S. G., \& Guneri, O. Y., (2011). Exploring the Factors Contributing to Empowerment of Turkish Migrant Women in the UK. International Journal Of Psychology, 46(3), 223-233. Doi: 10.1080/00207594.2010.532800.

Chee, H. H., Filzah, M. I., Cheng, W. H., Norashidah, H., Jasmani, M. Y. \& Haim, H. A. (2012). Development of Women Entrepreneurs: The Case of Malaysia. World Journal of Social Sciences, 2(6), $123-145$.

Cheon, E. S. (2003). Health and Welfare, Daekyengbooks.

Corsun, D. L., \& Enz, C. A. (1999). Predicting Psychological Empowerment Among Services Workers: The Effect Of Support-Based Relationships. Human Relations, 52, 205-224.

Department of Social Welfare. (2011). Department of Social Welfare website. Retrieved from http://www.jkm.gov.my/.

Department of Social Welfare. (2016). Terma Rujukan Pengurusan Projek Rintis 2 Years Exit Programme. Bahagian Kebajikan Produktif, Jabatan Kebajikan Masyarakat. Ministry of Women, Family and Community Development.

Department of Social Welfare. (2020). Department of Social Welfare website. Retrieved from http://www.jkm.gov.my/.

Department of Statistics Malaysia. (2017). Report of Household Income and Basic Amenities Survey 2016. Putrajaya: Malaysia.

Han, S.-J. (2002). The Third Way of Korea (Hankookhyung je sam ui gil ul saengakhanda). Policy Forum, Spring, 4-19.

Harian Metro. (2020). Pendapatan garis kemiskinan kini RM2,208. Harian Metro.10 Julai2020.https://www.hmetro.com.my/mutakhir/2020/07/598486/pendapatan-gariskemiskinan-kini-rm2208.

Hudson, J. \& Kuhner, S. (2009). Towards Productive Welfare? A Comparative Analysis of 23 OECD Countries. Journal of European Social Policy, 19(1), 34-46.

Hudson, J.R. \& Kühner, S. (2012). Analyzing the Productive and Protective Dimensions of Welfare: Looking Beyond the OECD. Social Policy and Administration, 46(1), 35-60. DOI: $10.1111 / \mathrm{j} .1467-9515.2011 .00813 . \mathrm{x}$.

Hudson, J., Kuhner, S., \& Yang, N. (2014). Productive Welfare, the East Asian 'Model' and Beyond: Placing Welfare Types in Greater China into Context. Social Policy and Society, 13(2), 301315. doi: $10.1017 /$ S14746413000573

Jisun, K. (2008). 'Self-reliance Program' in South Korea: Focused on the Experiences of the Participants. paper presented in the 17th Biennial Conference of the Asian Studies Association of Australia in Melbourne 1-3 July.

Joon, Y. J. (2014). Welfare Policy for a Sustainable Development: Korea's Productive Welfare and the National Basic Livelihood Security System1.

Kedah Department of Social Welfare. (2015). Kedah Department of Social Welfare website. Retrieved from http://www.jkm.gov.my/.

Ministry of Women, Family and Community Development. (2015). Ministry of Women, Family and Community Development Portal. Retrieved from http://www.kpwkm.gov.my/nkra/definisi. 
Asian Social Work Journal (ASWJ), Volume 6, Issue 3, (page 1 - 12), 2021

DOI: https://doi.org/10.47405/aswj.v6i3.169

Khairul, A. A. (2019). Keberkesanan Sistem Pengurusan Kes (CMS) Kerja Sosial dalam 2 Years Exit Programme (2YEP) Jabatan Kebajikan Masyarakat', MASW-JKM-ISM International Social Work Symposium 27 \& 28 April, 229-236.

Lightfoot, S. L.(1986). On Goodness of Schools: Themes of Empowerment. Journal of Education, 63(3), 9-28.

London, M. (1993). Relationships Between Career Motivation, Empowerment and Support for Career Development. Journal of Occupational and Organizational Psychology, 66(1):55-69. doi:10.1111/j.20448325.

Maton, K.I.(2008). Empowering Community Settings: Agents of Individual Development, Community Betterment, and Positive Change. American Journal of Community Psychology, 41: 4-21. doi:10.1007/s10464-007-9148-6.

Mohd Zahir, Z. (2009). Persepsi kumpulan sasar terhadap skim bantuan Jabatan Kebajikan Masyarakat di Wilayah Persekutuan Kuala Lumpur. Tesis Sarjana Sains, Universiti Putra Malaysia (tidak diterbitkan).

Noraida, I. et al., (2018). 'Kajian penilaian outcome: Program exit bagi penerima bantuan Jabatan Kebajikan Masyarakat yang produktif', Jurnal Kebajikan Masyarakat, 45, 109-118.

Putri, N. M. T., Khairuddin, I., Nur Aira, A. R., \& Mohd, M. A. (2020). Keusahawanan mampan melalui proses pemerkasaan sosioekonomi dalam kalangan usahawan bimbingan program 2 years exit programme yang berjaya di Negeri Sembilan, Malaysia. Community, 6(1), 83-91.

Radieah, M. N., \& Hamoon, K.D. (2019). 1AZAM Programme: The challenges and prospects of poverty eradication in Malaysia. International Journal of Academic Research in Business and Social Sciences, 9(1), 345-356.

Rohayu R., Marina, I. M., Ahmad, E., Sarebah, W., Maziana, M., Anizam, M. Y., \& Azmanirah, A. R. (2010) Pendidikan kemahiran keusahawanan dalam kalangan wanita ketua isi rumah luar bandar. In: Seminar Majlis Dekan Pendidikan IPTA, 2-3 Ogos 2010, Shah Alam.

Roller W. K. (1998). The Perception of empowerment instrument. Dicapai daripada Nhqualitycampaign.org/21/05/16.

Sabrina, O.S. (2019). Sustainability of Micro Entrepreneurs and Empowerment Perception: An Empirical Study in Indonesia. International Journal of Advanced Science and Technology, 28(8), 405-412.

Samat, N., Elhadary, Y.A, \& Rainis, R. (2016). Tackling Poverty Issues in Malaysia: A Spatial Dimensional Approach. 1st International Conference on Society, Space \& Environment 2016. Universiti Sains Malaysia, 2-4 November 2016, Bali, Indonesia.

Sarimah, C.H., Aidah, A. K., \& Norlizah, C.H., (2020). Memperkasa Usahawan Wanita Menerusi Pendidikan Teknikal dan Latihan Vokasional (TVET) dan Keusahawanan di Kolej Komuniti, Kementerian Pengajian Tinggi Malaysia. Jurnal Dunia Pengurusan, 2(3), 101-111.

Sharifah, N. S. A. R. et al. (2017). Laporan Akhir Kajian Keberkesanan Bantuan Kewangan Jabatan Kebajikan Masyarakat, Kementerian Pembangunan Wanita, Keluarga Dan Masyarakat. Serdang, Selangor.

Spreitzer, G. (1995). Psychological Empowerment in the Workplace: Dimensions, Measurement, and Validation. Academy of Management Journal, 3:1442-1465.

Spreitzer, G. (1996). Social Structural Characteristics of Psychological Empowerment. Academy of Management Journal, 39, 483-504.

Tenth Malaysia Plan. (2010). Tenth Malaysia Plan 2011-2015. Kuala Lumpur: National Printing.

Thuaibah @ Suaibah, A.B., Azlah, M.A., Hishamuddin, M.S., Rozeyta, O., Syaharizatul, N.M., dan Rossilah, M.J. (2004). Aktiviti keusahawanan di kalangan ibu tunggal di negeri Johor. Laporan Akhir Penyelidikan, Universiti Teknologi Malaysia.

Thuaibah @ Suaibah A. B., Azlah M. A., Rozeyta O., Hishamuddin M. S., \& Syaharizatul N. M. (2007). Penglibatan Kaum Wanita dalam Aktiviti Keusahawanan di Negeri Johor: Kajian Terhadap Faktor-Faktor Kritikal Kejayaan dan Kegagalan Pengendalian Perniagaan. Laporan Akhir Penyelidikan, Universiti Teknologi Malaysia.

Zahra S. A. (1999). The Changing Rules of Global Competitiveness in the 21st Century. Academy Of Management Executive, 13:36-42.

Zakiyah, J. \& Norzalinda, M.A.H. (2018). Poverty eradication through productive welfare aproach in Malaysia. International Journal of Academic Research in Business and Social Sciences, 8(9), 1186-1192. 
Asian Social Work Journal (ASWJ), Volume 6, Issue 3, (page 1 - 12), 2021

DOI: https://doi.org/10.47405/aswj.v6i3.169

Zakiyah, J. \& Norzalinda, M.A.H. (2020). Poverty and productive welfare in Malaysia. International Journal of Academic Research in Business and Social Sciences, 10(8), 917-923.

Zurinawaty, M., Nur Saadah, M.A., \& Nor Jana, S. (2020). Kebajikan produktif: Tahap dan hubungan kesejahteraan, tingkah laku dan pengalaman kewangan dalam kalangan peserta AZAM Tani FAMA. Jurnal Psikologi Malaysia, 34(2),13-27. 